\title{
Korešpondencia T. G. Masaryka so Slovákmi
}

\author{
Anna Zelenková (Praha)
}

Korespondence. T. G. Masaryk - slovenští veřejní činitelé (1918-1937). Eds. Jan Rychlík - Richard Vašek Miroslav Lacko. Praha: Masarykův ústav a Archiv AV ČR, v. v. i., 2019. 492 s. ISBN 978-80-88304-00-5.

Korešpondencia verejných činitelov má väčšinou úradný charakter a vel'kú dokumentárnu hodnotu, ale $\mathrm{v}$ prípade osobnosti prezidenta a filozofa T. G. Masaryka môže mat' okrem prezentácie politických postojov aj estetické a štylistické kvality. Tento aspekt sa objavil už v zborníku Masaryk a řeč (Praha, 1931), v ktorom napr. Jan Mukařovský vyzdvihol vecnost' a pragmatickost’ prezidentovho výkladového štýlu. To však podla neho môže mat' v súkromných prejavoch a spisoch aj náznak metafory a esejistiky, v čom by sa odrážala túžba rodeného polemika presviedčat svojich protivníkov jasnými argumentmi. Masaryk sa (a to nielen v súkromných listoch), ako píše publicista Jaroslav Pecháček v knihe Masaryk. Beneš. Hrad. Masarykovy dopisy Benešovi (München, 1986), prejavoval „celý, takový jako skutečně byl, z masa a krve“ (s. 7).

Tieto závery platia aj pre vydaný súbor Korespondence. T. G. Masaryk - slovenští veřejni činitelé (1918-1937), ktorý obsahuje 279 publikačných jednotiek odoslaných i prijatých Masarykom vo vzṫahu k medzivojnovému Slovensku. Bohužial, z tohto počtu je iba necelá pätdesiatka listov písaná Masarykom (odoslaná korešpondencia). Edíciu pripravili J. Rychlík, R. Vašek a M. Lacko a nadväzuje na predchádzajúci súbor Korespondence. T. G. Masaryk - slovenšti veřejni činitelé (do r. 1918) (Praha, 2007), editovaný iba J. Rychlíkom. Ten do oboch zväzkov napísal aj odborné úvodné štúdie, v ktorých zrekapituloval česko-slovenské politické vztahy. V stati Prvni republika, Slováci a T. G. Masaryk (s. 5-20) nadviazal na svoju monografiu Češi a Slováci ve 20. stoleti (Praha, 2012) a analyzoval Masarykov postoj k slovenským záležitostiam, jeho chápanie Čechov a Slovákov ako jedného politického národa s fiktívnym „„̌eskoslovenským jazykom“ v dvoch spisovných variantoch. Podla Rychlíka, Masaryk aj napriek silnej mad’arizácii objektívne nedocenil dosiahnutý stupeň národného uvedomovania Slovákov pred prvou svetovou vojnou a ako odporca slovenského autonomizmu hovoril iba o kultúrnej a administratívnej „svojráznosti“. Štúdia dokumentuje napr. okolnosti vstupu nacionalistov (vedených Andrejom Hlinkom) do vlády na konci dvadsiatych rokov 20. storočia, či tzv. Tukovu aféru založenú na predpokladanej, ale neexistujúcej tajnej klauzuly Martinskej deklarácie, podla ktorej bol zväzok českých historických zemí so Slovenskom uzatvorený iba dočasne na desat rokov, t. j. do roku 1928. Podla Rychlíka, názov Československo a pojem Čechoslovák „vznikly mnohem později než myšlenka společného státu“ (s. 5). V literárnohistorickom kontexte (no nie v politickom význame) sa dané označenie objavovalo v rôznych podobách už v19. storočí. Napr. M. M. Hodža sa 22. 9. 1833 na zasadnutí Zboru učencov prešpurského ústavu hlásil k spoločnej reči Čechov, Moravanov a Slovákov a na jej oslavu napísal do almanachu Plody (1836) báseň Československá reč. Ján Kollár má v Národných spievankách báseň Reč česko-slovenská síce s pomlčkou, ale s rovnakým významom. Bohuslav Tablic vydal v češtine v roku 1831 preklad z anglických osvietenských básnikov Anglické múzy v československém oděvu. V štúrovskom prostredí je do jazykovej kodifikácie - zjednodušene povedané - pojem „,̌eskoslovenský“ synonymný k výrazom „český“ a „slovenský“, a to v tom prípade, kde ide o spoločnú kultúrnu manifestáciu. A s názorom J. Rychlíka, vysloveným v prvom zväzku korešpondencie z roku 2007, že doktrínu čechoslovakizmu v medzivojnovom období nie je možné vnímat iba negatívne, sa dá iba súhlasit. Sám tvrdí, že bez 
nej by Československo nevzniklo. Táto doktrína slúžila ako argument pre vítazné mocnosti pri utváraní novo vzniknutého geopolitického priestoru, ktorý mal navonok vo vztahu k cudzine vystupovat ako národnostne a jazykovo monolitný. To si uvedomovali okrem Masaryka aj d’alšie osobnosti, ako napr. literárny historik Albert Pražák. Jeho predstava jednotnej „československej“ literatúry bola vedomou konštrukciou a účelovou hypotézou zameranou na medzinárodnú reprezentáciu novo vznikajúcej ideológie a kultúry.

Publikovaná korešpondencia poukazuje na to, že Masaryk udržiaval na Slovensku privátne kontakty aj po roku 1918. S niektorými, s hlasistickou a prúdistickou generáciou, sa poznal už z predvojnového obdobia, napr. s politikmi Milanom Hodžom, Vavrom Šrobárom atd', t. j. väčšinou s lud'mi z evanjelického kultúrneho okruhu. Medzi príjemcami však nachádzame aj mená slovenských spisovatel’ov, ako P. O. Hviezdoslav, E. Maróthy-Šoltésová, Š. Krčméry atd'. V korešpondencii niekedy nachádzame až dôverný tón a srdečné oslovenie, ktoré vystriedal $\mathrm{v}$ iných listoch úradný a zdvorilostný charakter. Napr. ide o list písaný po slovensky Andrejovi Hlinkovi z roku 1929, v ktorom Masaryk tohto „rozhnevaného“ slovenského politika a kňaza (ktorý v Tukovom procese veril $\mathrm{v}$ jeho nevinu, a preto vystúpil z vládnej koalície) vyzýval $\mathrm{k}$ demokratickej diskusii. V podtexte Masarykovej argumentácie dokonca stálo apelovanie na pozitívne city, ktoré by mali byt pre kňaza samozrejmé: „Dokážte, že máte srdce, že necítite len nenávist' $k$ tým svojim odporcom (opakujem zväčsa domnelým), ale že to svoje Slovensko, in concreto, teda Slovákov a Čechov tiež, aspoň trochu, milujete. Na nenávisti a zlobe, verte, nedá sa nič dobrého a trvalého vybudovat..." (s. 324).

Listy odrážajú aj Masarykov záujem o činnost' Matice slovenskej v Martine - už od osemdesiatych rokov 19 . storočia udržiaval o. i. kontakty so správcom MS Jozefom Škultétym a v medzivojnovom období napr. s tajomníkom MS Štefanom Krčmérym, ktorému (na prosbu Alice Masarykovej) zaistil štipendijný pobyt v Prahe a aj liečenie vo Švajčiarsku u svojho zata
MUDr. Revillioda. A napr. niektoré listy Krčméryho Masarykovi a opačne už boli predtým publikované1. Je však nevyhnutné vyzdvihnút rozsiahle pramenné štúdium editorov v českých a slovenských archívoch, napr. v Archíve Ústavu T. G. Masaryka a Archíve AV ČR, Archíve Kancelárie prezidenta republiky, v Literárnom archíve PNP v Prahe, Archíve Národného múzea, Archíve Matice slovenskej atd'. Zostavovanie kritických poznámok, bibliografických odkazov a rozsiahleho registra si v tomto prípade vyžiadalo náročnú prácu editorského tímu a dôležitú úlohu zohrávala aj jazyková stránka publikovaných listov.

Ak by sme sa vrátili k Masarykovmu štýlu $\mathrm{v}$ jeho korešpondencii, tak pre neho je - ako na to poukázal aj už v úvode spomenutý zborník - charakteristické navodenie bezprostrednej autentickosti, ktorá je však výrazom jeho výbornej štylizácie a prejavenej intuície. Počas celého svojho vedeckého a politického života písal filozofické texty, ale vystupoval aj ako literárny kritik, ktorý aj vo funkcii prezidenta polemizoval pod rôznymi pseudonymami so svojimi odporcami. A vol'bu štýlových prostriedkov vždy determinuje osobnost’ adresáta, či už ide bud' o umelca, politika, alebo vedca. Listy v publikovanom súbore velakrát prerastajú z výkladu do odbornej filozofickej úvahy, ktorá má z hladiska komunikácie charakter určitého asociatívne podaného apelu, u Masaryka ide totiž aj v osobnom liste o nenásilné vsúvanie určitých „miniúvah“ či stručných dôležitých výpovedí. Ale iba tažko sa dá vymedzit', ako by vlastne mala vyzerat' korešpondencia prezidenta v aktívnej funkcii. List je subjektívny žáner a Masaryk (a to aj pred nástupom do politickej funkcie) ho transformoval do akéhosi racionálneho typu spoločenskej kritiky, v ktorej sa objavuje aj citová výzva a musí byt založená - ako píše v liste A. Hlinkovi - „na politice skutečně mravni a dokonce křestanske".

1 ZELENKOVÁ, Anna: Slovenská prozódia a verzifikácia $v$ rukopise Štefana Krčméryho (1935). Praha: Slovanský ústav AV ČR - Euroslavica, 2006; ZELENKOVÁ, Anna: "Trúfal som si obrátit' svet naruby" (Štefan Krǒméry a jeho kontakty s T. G. Masarykom). In: Kultúra a súčasnost 4. Zošity č. 9/2006. Nitra: Fakulta stredoeurópskych štúdií Univerzity Konštantína Filozofa v Nitre, 2006, s. 64-78. 
Môžeme povedat', že ide o mimoriadny prínos do stále prebiehajúceho česko-slovenedičný čin, ktorý prispieva ku kompletizácii ského dialógu, resp. do česko-slovenských písomností spätých s osobnostou najvýznam- (a to nielen verejných) vztahov, ktoré ešte stále nejšieho politika a prezidenta v našich spoloč- nie sú dostatočne zdokumentované a interprených dejinách. Ale ide aj o interdisciplinárny tované.

\section{doc. PhDr. Anna Zelenková, Ph.D.}

Slovanský ústav AV ČR, v. v. i.

Valentinská 1, 11000 Praha 1, Česká republika

zelenkova.anna@centrum.cz 